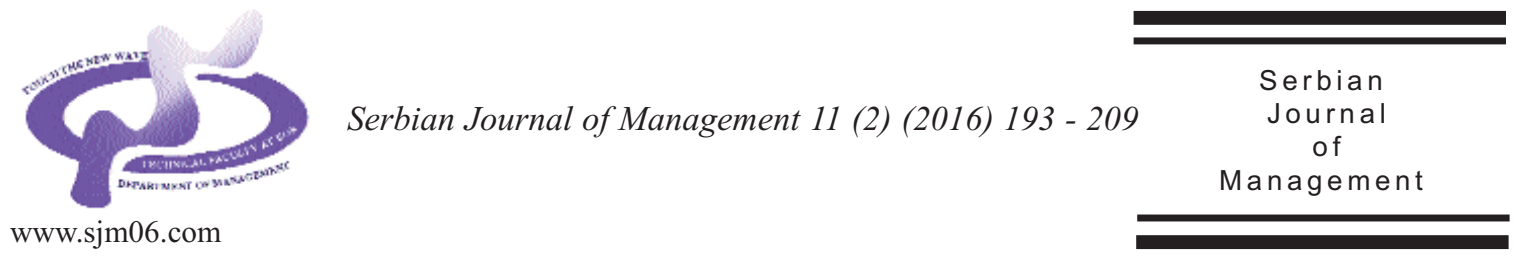

\title{
SYSTEM DYNAMICS MODEL FOR EVALUATION OF REUSE OF ELECTRONIC WASTE ORIGINATED FROM PERSONAL COMPUTERS
}

\author{
Eugênio Simonetto ${ }^{a^{*}}$, Osvaldo Quelhas ${ }^{b}$, Vesna Spasojević Brkićc, Goran Putnik ${ }^{d}$, \\ Cátia Alvesd and Hélio Castrod

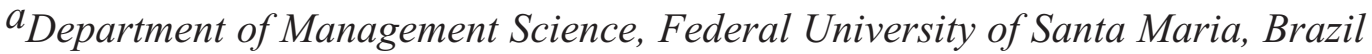

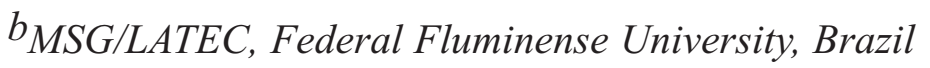 \\ ${ }^{c}$ Faculty of Mechanical Engineering, University of Belgrade, Serbia

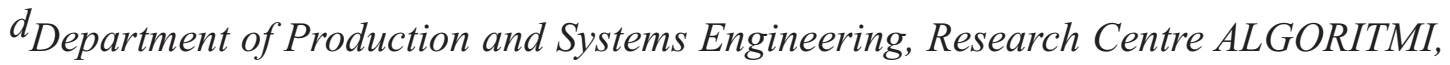 \\ University of Minho, Portugal
}

(Received 16 May 2016; accepted 13 July 2016)

\begin{abstract}
Information and Communication Technologies (ICT) are part of the day to day activities of a large part of world population, however its use involves a growing generation of electronic waste (ewaste).Due to the increasing technological innovation, it occurs that in a short time, the products become obsolete and have their life cycle reduced. The article aims to present the development, verification and validation of models of computational simulation for assessment of environmental and financial impacts caused by the extension of the life cycle of personal computers (PC) through their remanufacturing. For the system modeling the System Dynamics theory was used. Results generated by the simulation model, show that the remanufacturing is a viable alternative for the reutilization of discarded computers and that it is possible, in advance, to discuss, assess and decide necessary measures for a better financial and environmental performance in the acquisition and use of ICT.
\end{abstract}

Keywords: System dynamics, computers remanufacturing, reuse, electronic waste

\section{INTRODUCTION}

The use of Information and Communication Technologies (ICT) in the people's daily life is a real and unquestionable fact that includes the use of personal computers (PCs and notebooks), portable devices (Blackberry smart phones and tablets), printers and communication devices (fiber optic, communication cables

\footnotetext{
* Corresponding author: eosimonetto@gmail.com
}

DOI:10.5937/sjm11-10944 
and equipment). Due to the constant changes caused by technological developments, such ICTs become obsolete and are discarded by their users, thus generating electronic waste (e-waste).

Ferrer (1997) has noticed two decades ago that the personal computers and printers are durable consumer goods which have relatively short life cycle, but their components can have extended life cycles. On the other hand, the correct treatment of waste is among the most important issues for the quality of the environment (Zutshi \& Sohal, 2002). Despite of the concern of the international community, today in the majority of cases practices compromise the future of the next generations. The waste generated by electronic devices is highly polluting and harmful to human health due to its high toxicity.

Due to the range of problems that the inadequate treatment of waste generates, management on that topic increasingly attracts the attention of researchers in the area of modeling and systems (Huang et al., 1998; Simonetto \& Borenstein, 2007). This assertion is proven by the countless articles published in the area, that cover the allocation of vehicles for the residues collection (Bhat, 1996; Everett \& Shahi, 1997), modeling for evaluation of the environmental impact caused by the final residues destination (Perrodin et al., 2002), and even the articles involving the construction of models for the evaluation of the impact of best practices in waste management, of which can be mentioned (Golroudbary \& Zahraee, 2015; Parkes et al., 2015).

When dealing with the development of computational models to support the decision-making process associated to practices of Green ICTs, studies published are still scarce. The research by Kroth et al. (2015) refers to the analysis of best practice in the use of ICT, while Schneider et al. (2015) analyze the discard of computers and printers with respect to quantity purchased and propose the model, that highlights the proposition of recycling, reuse and, even the equipment donation to social entities. Other articles examine the question of ecoefficiency and compare remanufactured mobile phones to new products (Frota-Neto \& Bloemhof, 2009; Frota-Neto \& Bloemhof, 2012; Sahni et al., 2010). To minimize the impact of accelerated rhythms of industrialization, pollution and exploitation of natural resources caused by electronic devices, in this article new computational simulation models will be used to evaluate the environmental and financial impacts generated by the extension of the personal computers (PCs) life cycle, i.e., instead of being intended for collection or recycling of junk mail devices components of PCs (CPU, video monitors and input devices) are used as raw material for the manufacture of a "new personal computer" (remanufactured computer or remanufacturing computer). The results generated by the proposed model are intended to supply the managers in ICTs and environmental areas, as well as investors with information useful to decision-making process for development of best practices in disposing of electronic waste, i.e. the possible residue becoming raw material for the (re) manufacturing of equipment in total use condition.

The article is organized as follows: in section 2 the research method used for the development of the study is presented, as well as the hypothesis dynamic to be verified with the same. In section 3 the theoretical framework for the development of the study is described, where the concepts about the 
computers remanufacturing and the systems dynamics are presented. In section 4 the modeling problem, the component variables and the developed model are described. In section 5 the simulation scenarios, the validation and an experiment using the template are presented. Finally, concluding remarks are presented in section 6 .

\section{RESEARCH METHOD}

The research method for the development of the computational model herein is based on the methodology for systems modeling and simulation presented by Law (2015), which consists of the following steps: (1) exploratory studies in scientific articles, technical reports, interviews with stakeholders and observations of the environment where data were collected and through these data, the research problem is specified and structured; (2), solution development through the construction of formal models capable of representing the problem (definition of the variables and their relationships); (3) implementation of the computational solution, using the simulator Vensim (Ventana Systems, 2016) for the System Dynamics area; (4) the verification and validation $(V \& V)$ of the solution through the lab testing and analysis of historical behaviour (with the data that were available), to check whether the results obtained represent part of the observed reality, because in simulated environment there is no waste destination for remanufacturing, i.e. the final destination is the collection of electronic waste and (5) for the verification and validation of the model as a whole one case using three scenarios (reuse of $5 \%$, reuse of $40 \%$ and reuse of $70 \%$ ) was simulated to make comparison.
The model is designed, verified and validated according to the data obtained at the 26th Annual Survey of the use of Information Technology in Brazil (Meirelles, 2015), as well as personal computers discard data, and relating to the life cycle data were obtained in a higher education institution. The primary data, such as acquisition, discard rates and usage time of PCs, as the inputs of the model are collected from the Annual Survey of the use of Information Technology and in the institution that served as a case study for analysis. The data regarding values of remanufactured computers and energy consumption were extracted from Frota-Neto \& Bloemhof (2009), Frota-Neto \& Bloemhof (2012) and Sahni et al. (2010).

For the definition of the variables in the model, interviews with stakeholders were performed together with observations of the acquisition process and disposal from bibliographic sources (Frota-Neto \& Bloemhof, 2009; Frota-Neto \& Bloemhof, 2012; Giutini \& Gaudette, 2003; Hatcher et al., 2013; Meirelles, 2015; Schneider et al., 2015).

The main hypothesis of this research is that the quantity of personal computers has a direct influence on the total quantity of discarded computers, as well as in total quantity of computers available to the remanufacturing and to waste, thus, the higher remanufacturing indices and lower allocation to waste, the more financial resources are generated and $\mathrm{CO} 2$ emissions to the environment are more reduced.

\section{THEORETICAL REFERENCE}

Remanufacturing is the manufacturing process of a product from components that 
would have their life cycle ended, if this new process not turned out them to be the raw material. This new process adds up to the following production stages: inspection, disassembly, cleaning, reprocessing, reassembly and test (Hatcher et al., 2013). Regarding the life cycle of the new and remanufactured computers, Frota-Neto and Bloemhof (2009) affirmed that the remanufacturing process adds three new stages to traditional manufacturing process: the remanufacturing itself, the transport of remanufactured product and the time of extra life that the product acquires.

Accordingly, the most important benefit of remanufacturing is the extension of the life cycle of the product (Frota-Neto and Bloemhof, 2009). The remanufacturing process has advantages over the traditional manufacturing, as the customer pays less for the product, the organization spends less to manufacture it and the process consumes less virgin raw material and energy than the traditional production process (Sundin \& Dunbäck, 2013). According to Giutini and Gaudette (2003), the production cost of a remanufactured product is $40-65 \%$ less than a new product, the final price to the consumer is $40 \%$ lower and it is possible to save annually the equivalent of 16 million barrels of oil through this process. FrotaNeto and Bloemhof (2012), after detailed comparative analyzes of new computers prices in relation to the price of similar remanufactured, conclude that time has a negative influence on the residual price, as shown in Table 1.

Researchers in the area of Green IT address among the best practices the importance of the reduction of energy consumption (Dragićević \& Bojić, 2009), but the remanufacturing computers are poorly addressed and treated only through reuse (Dias et al, 2013; Faria et al., 2013; Lunardi et al., 2011; Muruguesan, 2008; Lunardi et al., 2014). When examining the energy consumption during the life cycle of new PCs, Frota-Neto and Bloemhof (2012) have analized energy consumption during product manufacturing, during usage time of the product (with an average time of 4 years) and energy consumption by the transportation of the product to the final consumer. The results using average values on energy demand are presented in Table 2.

In the case of remanufactured PCs three new steps should be considered in the calculation of energy consumption, because there are energy demands for remanufacturing, transporting from previous to the new consumer and also duration time of the remanufactured product usage (FrotaNeto \& Bloemhof, 2012). The average values obtained in Frota-Neto and Bloemhof (2012) study concerning the comparison of the energy consumption of remanufactured and new computers are shown in Table 3 and it is noticeable that the energy consumption in transport phase remains the same as in case of a new computer.

Table 1. The ratio of the residual price with the computer use time

\begin{tabular}{cc}
\hline Computer Use Time & Residual price (compared to new product) \\
\hline Less than 3 years & $62.2 \%$ \\
Between 4 and 5 years & $22.5 \%$ \\
Between 6 and 8 years & $10.2 \%$ \\
More than 8 years & $8.3 \%$ \\
\hline
\end{tabular}

Source: Frota-Neto \& Bloemhof (2009) 
Table 2. Average energy demand in the life cycle of a new PC

\begin{tabular}{ccc}
\hline Life Cycle stage & Energy demand (MJ) & Energy demand \% \\
\hline Manufacturing & 6180 & 77.8 \\
Usage & 1733 & 21.9 \\
Transport & 28 & 0.3 \\
Total & 7941 & 100 \\
\hline
\end{tabular}

Source: Frota-Neto \& Bloemhof (2012)

Table 3. A comparison of the energy consumption of remanufactured and new PCs

\begin{tabular}{ccc}
\hline & $\begin{array}{c}\text { Similar energy } \\
\text { consumption }\end{array}$ & $\begin{array}{c}\text { 30\% higher energy } \\
\text { consumption }\end{array}$ \\
\hline Reduced life cycle (25\% of the new product) & & \\
Low level of energy in remanufacturing & $43.5 \%$ & $52.0 \%$ \\
High level of energy in remanufacturing & $116.5 \%$ & $124.5 \%$ \\
Long life cycle (100\% of the new product) & & $31.0 \%$ \\
Low level of energy in remanufacturing & & $39.5 \%$ \\
High level of energy in remanufacturing & $49.5 \%$ & $57.5 \%$ \\
\hline
\end{tabular}

Source: Frota-Neto \& Bloemhof (2012)

Thus, the remanufacturing of $\mathrm{PCs}$ is shown as a viable alternative in both economic (lower cost product) and environmental requirements (product that consumes less energy in its life cycle). Accordingly, in this paper will be sought to assess and quantify the benefits of the remanufacturing process of personal computers, through the development of a computational simulation model using the systems dynamics.

The methodology of System Dynamics is developed by Forrester in 1950, making possible to study the behaviour of systems with regard to passing of time and allowing users to assess the consequences of their decisions in a future time horizon (Daellenbach et al., 2012). The structure of models in system dynamics consists of the inventories and the flows and Ford (2009) defines the systems dynamics as a method that combines flows and inventories in a computational structure to be simulated. Inventories relate to the variables in the model that are accumulated in the system while the flows are the decisions or policies of the system. Those components can be organized in the form of cause and effect relationships, named balance feedback or strengthening, and are subject to time gaps in the system under analysis. Several authors use systems dynamics methodology to analyses of issues related to the environment and sustainability, among them Sufian and Bala (2007); Abeliotis et al. (2009); Dyson and Chang (2005); Djordjevic et al. (2010); Kum et al. (2005); Savic et al. (2015) and Simonetto (2014). The model developed by Poles and Cheong (2009) may be highlighted since it aims to evaluate possible improvements in the components phases to reduce the total production costs. Also, study by Vlachos et al. (2007) uses the systems dynamics to develop capacity.

Planning model for the remanufacturing supply chain, that takes into account both economic and environmental aspects. In this paper the system dynamics methodology is used because it enables to assess environmental and economic benefits of personal computers intended for electronic waste collection (second-handed computers) remanufacturing in a future time horizon. 
4. DEVELOPMENT OF SIMULATION MODEL

In Figure 2, the structure of the model and the variables used, as well as their interrelationships, are presented on the basis of previous research (Frota-Neto \& Bloemhof, 2009; Frota-Neto \& Bloemhof, 2012; Giutini \& Gaudette, 2003; Schneider et al., 2015). Figure 1 shows the model structure, while Figure 2 presents the cause-effect diagram of the model, where is noticeable that model consists of three sub models: (a) Acquisition/
Discard, (b) Remanufactured PC; and (c) Benefits Evaluation Submodel. In the following subsections, the sub models and their modeling using the systems dynamic will be shown.

\subsection{Submodel Acquisition/Discard}

The submodel Acquisition/Discard aims to model the behaviour concerning the acquisitions and, later, computers discard. The inventory components variables of this submodel are the number of personal

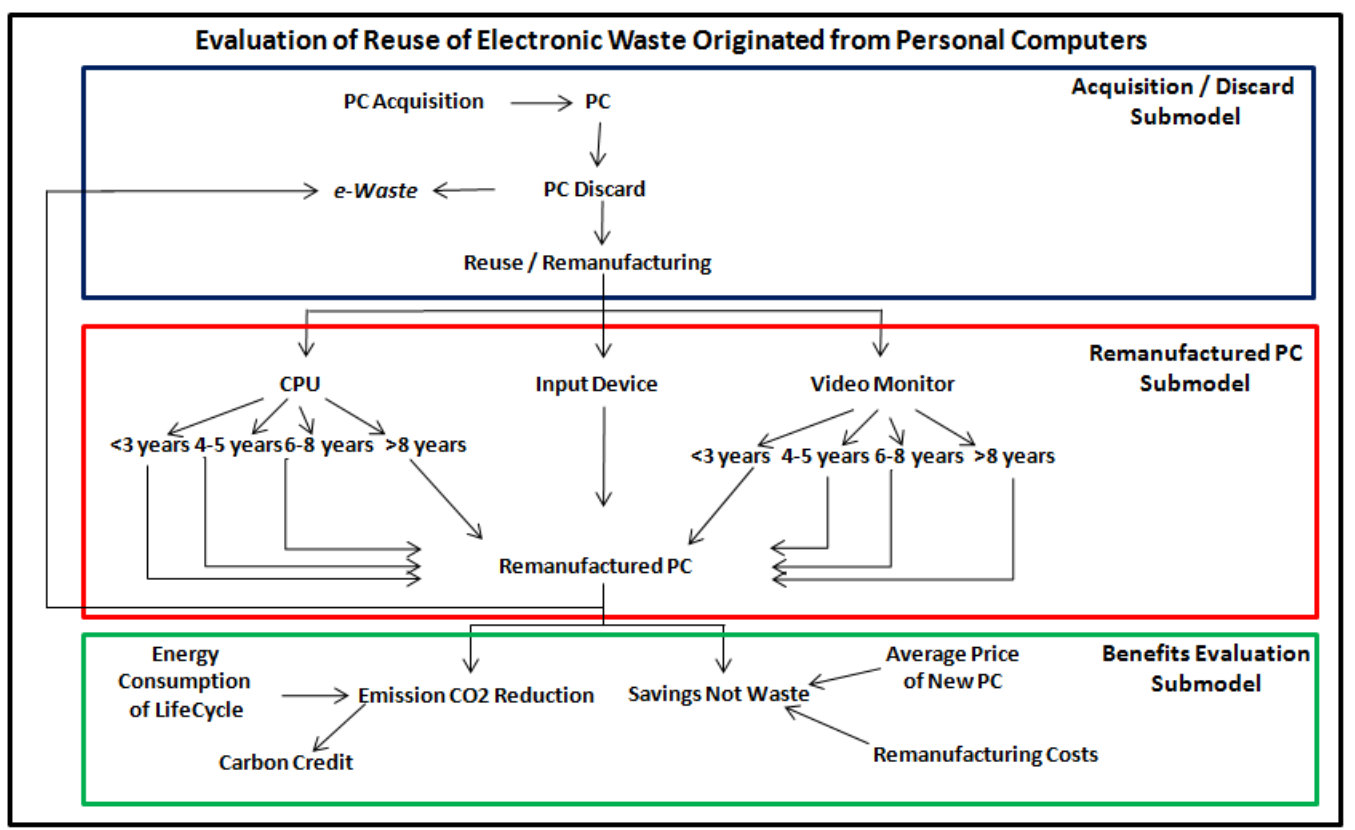

Figure 1. Structuring of the model

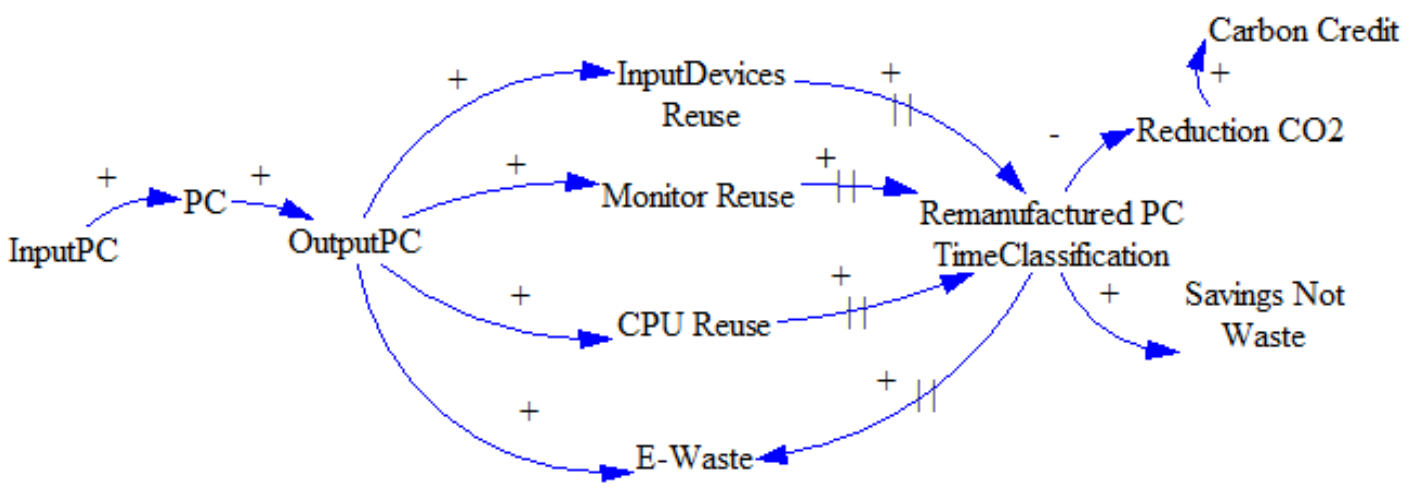

Figure 2. Casual-loop diagram of the model 
computers in use in the modeled environment (PC), the quantity of monitors

(Monitor Reusable), input devices (InputDev Reusable) and CPUs (CPU Reusable) possible to be reused in the remanufacturing process, as well as, the devices that do not have conditions to be remanufactured (Monitor e-Waste, CPU eWaste and InputDev e-Waste). The flow variables used, as well as their auxiliary variables are the input (acquisition) of computers (InputPC) determined by annual quantity of equipment acquired (QuantIn), the discard of computers (OutPC) directly related to annual quantity of equipment directed to discard (QuantOut). The flows of devices directed to each year to the remanufacturing (InputMon, InputInDev and InputCPU) are defined by the rates of possible components to be reused (Reuse Monitor Rate, Reuse CPU Rate and Reuse InDevRate) and associated to each one of these, taking into account the total of PCs discarded to obtain the total of each device. To obtain the flow variables related to the devices that will be sent annually to the electronic waste (QtMon e-Waste, QtCPU e-Waste and QtInput e-Waste) the total quantity of discarded computers subtracting from that value the quantity of devices available to the remanufacturing is used, while the quantity of remanufactured computers discarded after their life cycle is added to the value obtained. Figure 3 shows the systems dynamics diagram of submodel Acquisition/Discard. In Figure 6 the equations (equations 1 to 15) components of this submodel are presented, in its turn, the values assigned to the variables are described in Table 4.

\subsection{Submodel Remanufactured PC}

The remanufactured PC submodel has as a principle the flow variables InputCPU InputInDev and InputMon, of the sub model Acquisition / Discard. These variables are used for the determination of the quantity of computational devices available to the remanufacturing (QuantCPU < 3, QuantCPU 45, QuantCPU 68, QuantCPU > 8, QuantMon < 3, QuantMon 45, QuantMon 68, QuantMon $>$ 8). The variables are defined according to the classification of time and use as proposed by Frota-Neto and Bloemhof (2009), which is also used for the definition of the residual price and energy consumption. For the definition of the quantity of input devices to be used

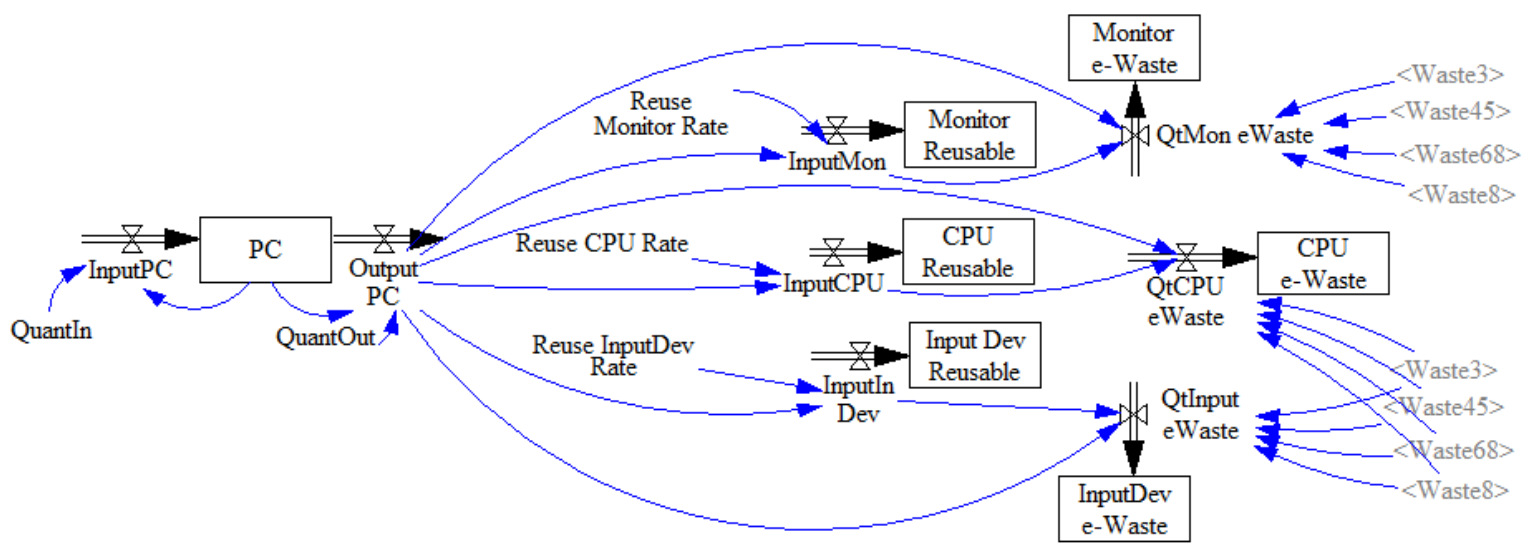

Figure 3. System Dynamics diagram of submodel Acquisition / Discard 
(keyboards and mice) the variable InputInDev as maintained, due to the fact that these components are compatible with other hardware devices regardless of the usage time. Still, for the definition of devices with relation to its usage time, the variables RateCPU3, RateCPU45, RateCPU68, RateCPU8, RateMon3, RateMon45, RateMon68, QuantMon8 are added, to represent the percentage of devices of each type of temporal classification in the total of devices designed to discard. After definition of the variables relating to quantities of hardware devices (by usage time), they are used for composition of flow variables InpPCRem<3y, InpPCRem4y5y, InpPCRem 6y8y and InpPCRem $>8 y$ that represent the number of computers to be remanufactured every simulated year. For the definition of these flow variables the consideration possible production time of computers is taken into, since the entire device available for remanufacturing must comply with the steps of the remanufacturing process (Hatcher et al., 2013). For the definition of the quantity of computers to be produced, the number of devices with a smaller quantity available is used as a parameter at the time of decision. The variables that represent the production time (delay) are ProdTime $<3 y$, ProdTime4y5y, ProdTime6y8y and ProdTime $>8 y$. The auxiliary variables Input3, Input45, Input68 and Input8 are used to assist in determining the equations relating to flow variables. Finally, the variables of inventory of submodel represent the total computers of each type produced during the simulated time (PC Reman<3y, PC Reman 4y5y, PC Reman 6y8y and PC $\operatorname{Reman}>8 y$ ). Remanufactured computers also have a life cycle of usage, thus after that time (UseTime3, UseTime45, UseTime68 and
UseTime8) they are discarded to the electronic waste. This characteristic is represented in the model using the Variables Waste3, Waste45, Waste68 e Waste8 which correspond to the number of computers that will be annually remanufactured/sent to electronic waste (QtMon e-Waste, QtCPU e-Waste and QtInput e-Waste). Figure 4 shows the Remanufactured PC submodel while the equations of the submodel and the values assigned to the variables are presented in Figure 7 (equations 16 to 39) and in Table 4.

\subsection{Submodel Evaluation of benefits}

The last submodel Evaluation of Benefits includes the reduction of $\mathrm{CO}_{2}$ emissions in the environment and the generated financial benefits. The submodel, shown in Figure 5, begins with the total of remanufactured (InpPCRem<3y, InpPCRem 4y5y, InpPCRem 6y8y and InpPCRem>8y) which is a part of the equations where the flow variables of the annual reduction in the emission of carbon dioxide are obtained (YearReducCO2) and the annual savings originated by remanufacturing of the PCs (YearSavMoney). The auxiliary variable TotalPCLifeCycleDemandedEnergy is necessary to assign to the possible consumption by the PCs in their traditional and extended lives cycles. To determine the reduction of the emission of $\mathrm{CO}_{2}$ (YearReducCO2) the amount of energy used by a new computer throughout its life cycle is taken into account, however, a remanufactured computer may not consume the same amount as a new one. Thus, based on the premise that each remanufactured computer is a new computer less in use, the equation for calculation of the reduction of the emission of $\mathrm{CO}_{2}$ in the atmosphere is defined. 
The auxiliary variables

(2009) is applied. The inventories variables PCAvgValueandRemanufacturingCosts SavingsNotWaste and Reduction CO2 are used for the calculation of financial gain obtained through remanufacturing. For the determination of the equation of the gains obtained annually with the sale of remanufactured computers Emission represent the total accumulated along the simulated time, while the variable CarbonCredit represents the total obtained in collection of selling the carbon credits (YearSavMoney) the quantity of each type of remanufactured computer is taken into consideration (with respect to usage time) and the reduction factor of the price of a new product according to the temporal classification by Frota-Neto and Bloemhof obtained with the reduction of the demand of energy used by remanufacturing compared to traditional manufacturing. The equations referring to submodel, as well as the values assigned to the variables are presented in figure 6 (equations 40 to 44) and in Table 4.

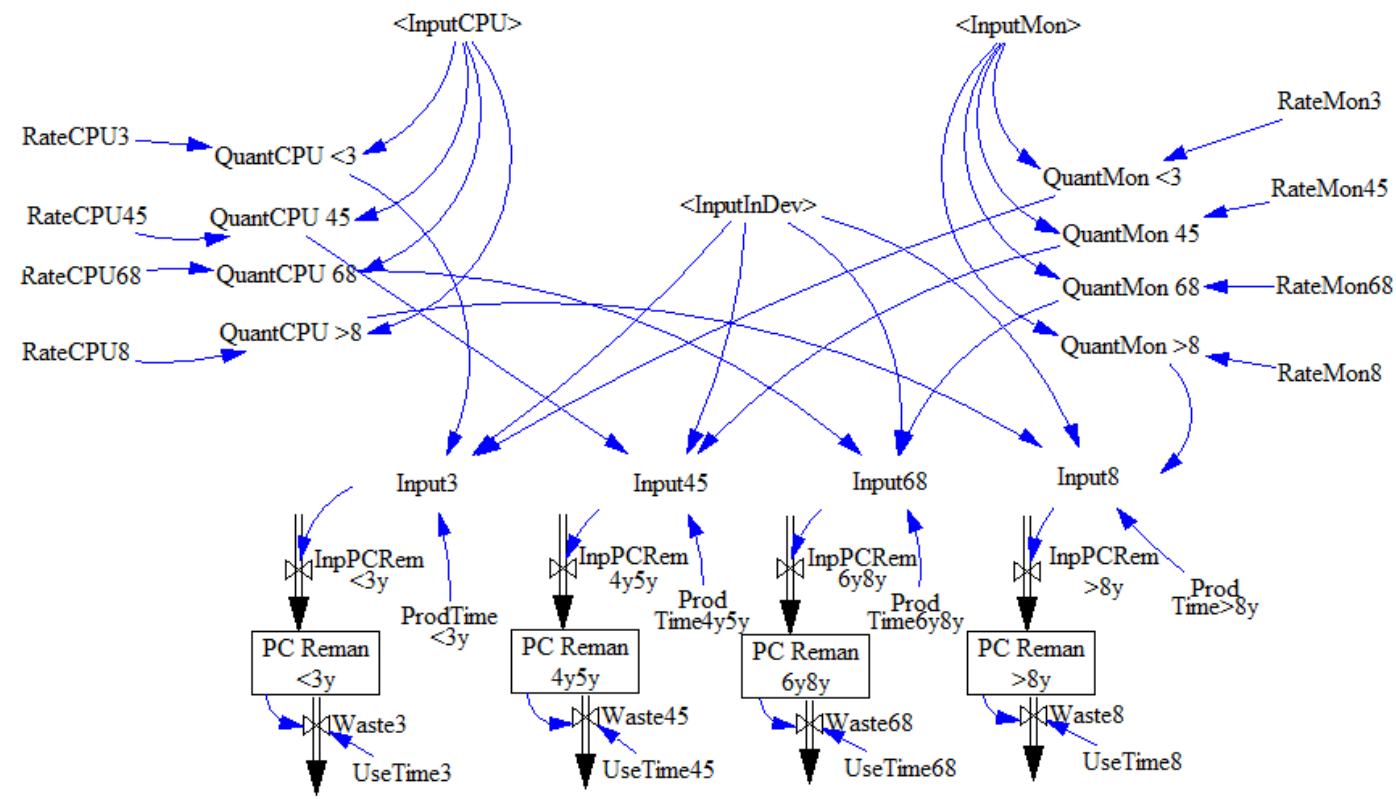

Figure 4. Systems Dynamic Diagram of Remanufactured PC submodel

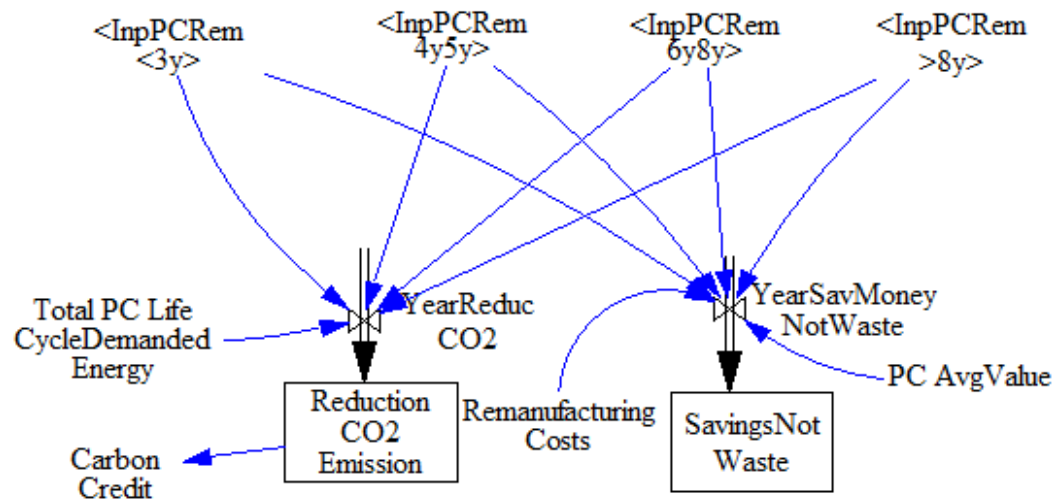

Figure 5. Systems Dynamic Diagram of evaluation of benefits submodel 


\begin{tabular}{|c|c|}
\hline (1) & InputPC $(t)=$ QuantIn $(t)$ \\
\hline (2) & OutputPC $(t)=$ QuantOut $(t)$ \\
\hline (3) & $\mathrm{PC}(t)=\mathrm{PC}(t-1)+\operatorname{InputPC}(t)-$ OutputPC $(t)$ \\
\hline (4) & $\operatorname{InputCPU}(t)=\operatorname{OutputPC}(t) *$ Reuse CPURate $(t)$ \\
\hline (5) & $\operatorname{InputInDev}(t)=\operatorname{OutputPC}(t) *$ Reuse InputDevRate $(t)$ \\
\hline (6) & $\operatorname{InputMon}(t)=$ OutputPC $(t) *$ Reuse MonitorRate $(t)$ \\
\hline (7) & QtCPU eWaste $(t)=$ Output PC $(t)$-InputCPU $(t)$ \\
\hline (8) & QtInput eWaste $(t)=$ Output $\mathrm{PC}(t)$-InputInDev $(t)$ \\
\hline (9) & QtMon eWaste $(t)=$ Output PC $(t)$-InputMon $(t)$ \\
\hline (10) & CPU Reusable $(t)=$ CPU Reusable $(t-1)+\operatorname{InputCPU}(t)$ \\
\hline (11) & Input Dev Reusable $(t)=$ Input Dev Reusable $(t-1)+\operatorname{InputInDev}(t)$ \\
\hline (12) & Monitor Reusable $(t)=$ Monitor Reusable $(t-1)+\operatorname{InputMon}(t)$ \\
\hline (13) & CPU e-Waste $(t)=$ CPU e-Waste $(t-1)+$ QtCPU eWaste $(t))+$ Waste3 $(t)+$ Waste $45(t)+$ Waste68 $(t)+$ Waste $8(t)$ \\
\hline (14) & InputDev e-Waste $(t)=$ InputDev e-Waste $(t-1)+$ QtInput eWaste $(t)+$ Waste $3(t)+$ Waste $45(t)+$ Waste68 $(t)+$ Waste $8(t)$ \\
\hline (15) & Monitor e-Waste $(t)=$ Monitor e-Waste $(t-1)+$ QtMon eWaste $(t))+$ Waste3 $(t)+$ Waste45 $(t)+$ Waste $68(t)+$ Waste $8(t)$ \\
\hline (16) & QuantCPU45 $(t)=\operatorname{InputCPU}(t) * \operatorname{RateCPU} 45(t)$ \\
\hline (17) & QuantCPU68 $(t)=\operatorname{InputCPU}(t) * \operatorname{RateCPU} 68(t)$ \\
\hline (18) & QuantCPU $<3(t)=\operatorname{InputCPU}(t) * \operatorname{RateCPU} 3(t)$ \\
\hline (19) & QuantCPU $>8(t)=\operatorname{InputCPU}(t)^{*} \operatorname{RateCPU} 8(t)$ \\
\hline (20) & QuantMon45 $(t)=\operatorname{InputMon}(t) * \operatorname{RateMon} 45(t)$ \\
\hline (21) & QuantMon68(t) $=$ InputMon $(t) *$ RateMon68(t) \\
\hline (22) & QuantMon<3(t)= InputMon $(t) * \operatorname{RateMon} 3(t)$ \\
\hline (23) & QuantMon $>8(t)=\operatorname{InputMon}(t) * \operatorname{RateMon} 8(t)$ \\
\hline (24) & Input3 $(t)=$ DELAY $(\mathrm{MIN}(\mathrm{QuantCPU}<3(t)$,InputInDev $(t)$, QuantMon<3(t)),ProdTime $<3 \mathrm{y}(t), 0)$ \\
\hline (25) & Input45 $(t)=$ DELAY $(\operatorname{MIN}($ QuantCPU45 $(t), \operatorname{InputInDev}(t), \mathrm{QuantMon45}(t)), \operatorname{ProdTime} 4 \mathrm{y} 5 \mathrm{y}(t), 0)$ \\
\hline (26) & Input68 $(t)=$ DELAY $($ MIN $(Q u a n t C P U 68(t), \operatorname{InputInDev}(t)$, QuantMon68 $(t))$, ProdTime6y8y $(t), 0)$ \\
\hline (27) & Input8 $(t)=$ DELAY $(\mathrm{MIN}(\mathrm{QuantCPU}>8(t)$, InputInDev $(t)$, QuantMon $>8(t))$, ProdTime $>8 \mathrm{y}(t), 0)$ \\
\hline (28) & $\operatorname{InpPCRem} 4 y 5 y(t)=\operatorname{Input} 45(t)$ \\
\hline (29) & $\operatorname{InpPCRem6y8y}(t)=\operatorname{Input68}(t)$ \\
\hline (30) & $\operatorname{InpPCRem}<3 y(t)=\operatorname{Input} 3(t)$ \\
\hline (31) & $\operatorname{InpPCRem}>8 y(t)=\operatorname{Input} 8(t)$ \\
\hline (32) & PC Reman4y5y $(t)=$ PC Reman4y $5 y(t-1)+\operatorname{InpPCRem} 4 \mathrm{y} 5 \mathrm{y}(t)$ \\
\hline (33) & PC Reman6y8y $(t)=$ PC Reman6y8y $(t-1)+\operatorname{InpPCRem} 6 y 8 y(t)$ \\
\hline (34) & PC Reman<3y $(t)=$ PC Reman<3y $(t-1)+\operatorname{InpPCRem}<3 y(t)$ \\
\hline (35) & PC Reman $>8 y(t)=$ PC Reman $>8 y(t-1)+\operatorname{InpPCRem}>8 y(t)$ \\
\hline (36) & Waste3 $(t)=$ PC Reman $<3 y(t) /$ UseTime3 $(t)$ \\
\hline (37) & Waste45 $(t)=$ PC Reman4y5y $(t) /$ UseTime45 $(t)$ \\
\hline (38) & Waste68 $(t)=$ PC Reman6y8y $(t) /$ UseTime68(t) \\
\hline (39) & Waste $8(t)=$ PC Reman $>8 y(t) /$ UseTime $8(t)$ \\
\hline \multirow[t]{4}{*}{ (40) } & $\begin{array}{l}\text { YearReducCO2 }(t)=(((\text { Total PCLifeCycleDemandedEnergy }(t)-(\text { Total PCLifeCycleDemandedEnergy }(t) \\
\left.*_{0.31}^{*} \text { InpPCRem }<3 \mathrm{y}(t)\right)+(\text { Total PCLifeCycleDemandedEnergy }(t)-(\text { Total PCLifeCycleDemanded }\end{array}$ \\
\hline & Energy $\left.(t)^{*} 0.31\right)^{*}$ InpPCRem $\left.4 y 5 y(t)\right)+($ Total PC LifeCycleDemandedEnergy $(t)+($ Total PC \\
\hline & LifeCycleDemandedEnergy $(t) * 0.435)^{*}$ InpPCRem 6y8y $\left.(t)\right)+($ Total PC LifeCycle Demanded Energy $(t)+$ Total \\
\hline & PC LifeCycleDemanded Energy $(t) * 1.1165) * \operatorname{InpPCRem}>8 \mathrm{y}(t))) / 3600 * 462.375$ \\
\hline (41) & YearSavMoneyNotWaste $(t)=(\operatorname{InpPCRem}<3 \mathrm{y}(t) * \operatorname{PCAvgValue}(t) * 0.622)+\left(\operatorname{InpPCRem} 4 \mathrm{y} 5 \mathrm{y}(t) * \operatorname{PCAvgValue}(t)^{*} 0\right.$. \\
\hline & $\begin{array}{l}\text { 225)+(InpPCRem 6y8y }(t) * \operatorname{PC} \text { AvgValue }(t) * 0.102)+(\operatorname{InpPCRem}>8 \mathrm{y}(t) * \operatorname{PCAvgValue}(t) * 0.083)- \\
(\operatorname{InpPCRem}<3 \mathrm{y}(t)+\operatorname{InpPCRem} 4 \mathrm{y} 5 \mathrm{y}(t)+\operatorname{InpPCRem6y} 8 \mathrm{y}(t)+\operatorname{InpPCRem}>8 \mathrm{y}(t))^{*} \operatorname{RemanufacturingCosts}(t)\end{array}$ \\
\hline (42) & ReductionCO2 Emission $(t)=$ ReductionCO2 Emission $(t-1)+$ YearReducCO2(t) \\
\hline (43) & Savings $(t)=$ Savings $(t-1)+$ YearSavMoneyNotWaste $(t)$ \\
\hline (44) & CarbonCredit $(\mathrm{t})=$ ReductionCO2 Emission $(t) * 10$ \\
\hline
\end{tabular}

Figure 6. Equations of the simulations model

\section{VERIFICATION, VALIDATION AND EXPERIMENTAL PROOF OF THE MODEL}

In the development of the model the verification and the validation are needed in all stages of their conception. Herein, in the first phase (conceptual model), data from scientific papers, reports of purchase and discard were used together with the participation of stakeholders of higher education institution (HEI) to define the variables in the proposed model. In the second phase, concerning the implementation at the Vensim simulator (Ventana Systems, 2016), historical data for 
the verification of the integration between the modules and model components were used, as well as the results generated. In both cases the results were satisfactory and have met the expectations of designers. In the third phase data and rates from a public HEI were used. The remanufacturing of computers is not performed in the HEI where data were collected, but all rates of acquisition, discard, average value of acquisition, sale value of electronic waste and use times of PC are real, as well as the cost of labor are considered as zero, due to the fact that the institution may proceed to the remanufacturing using maintenance industry professionals for that.

The data for the calculation of the residual value of the remanufactured PC were obtained from Frota-Neto and Bloemhof (2009), while the value of the remanufacturing cost was estimated based on observations of the researchers in the HEI, where part of the data were collected. The equations relating to energy consumption in remanufactured PCs were developed on the basis of the study by Frota-Neto and Bloemhof (2012). Regarding the reduction of emission of $\mathrm{CO}_{2}$, the data are taken from EPA (2016).For the implementation of the third phase of validation of the model three scenarios were generated to be simulated: (a) $70 \%$ of reuse, (b) $40 \%$ of reuse and (c) $5 \%$ of reuse. The details of those scenarios are presented in table 4.

Table 4. Detailing of the scenarios simulated

\begin{tabular}{|c|c|c|c|}
\hline Rates & Reuse $70 \%$ & Reuse $40 \%$ & Reuse 5\% \\
\hline PCs input & $\begin{array}{l}6 \% \text { of Total PCs } 2016 \text { to } \\
2017,8 \% \text { in } 2018 \text { to } 2022 \text { and } \\
7.5 \% \text { from } 2023 \text { to } 2026\end{array}$ & $\begin{array}{l}6 \% \text { of Total PCs } 2016 \text { to } \\
2017,8 \% \text { in } 2018 \text { to } 2022 \text { and } \\
7.5 \% \text { from } 2023 \text { to } 2026\end{array}$ & $\begin{array}{l}6 \% \text { of Total PCs } 2016 \text { to } \\
2017,8 \% \text { in } 2018 \text { to } 2022 \text { and } \\
7.5 \% \text { from } 2023 \text { to } 2026\end{array}$ \\
\hline PCs discard & $\begin{array}{l}2.5 \% \text { in } 2016 \text { with growth of } \\
5 \% \text { a year }\end{array}$ & $\begin{array}{l}2.5 \% \text { in } 2016 \text { with growth of } \\
5 \% \text { a year }\end{array}$ & $\begin{array}{l}2.5 \% \text { in } 2016 \text { with growth of } \\
5 \% \text { a year }\end{array}$ \\
\hline Monitors reuse & $\begin{array}{l}\text { Increase from } 4 \% \text { up to } 70 \% \\
\text { on the } 10 \text { th year }\end{array}$ & $\begin{array}{l}\text { Increase from } 4 \% \text { up to } 70 \% \\
\text { on the } 10 \text { th year }\end{array}$ & $\begin{array}{l}\text { Increase from } 4 \% \text { up to } 5 \% \text { on } \\
\text { the } 10 \text { th year }\end{array}$ \\
\hline $\mathrm{CPU}$ reuse & $\begin{array}{l}\text { Increase from } 4 \% \text { up to } 70 \% \\
\text { on the } 10 \text { th year }\end{array}$ & $\begin{array}{l}\text { Increase from } 4 \% \text { up to } 40 \% \\
\text { on the } 10 \text { th year }\end{array}$ & $\begin{array}{l}\text { Increase from } 4 \% \text { up to } 5 \% \text { on } \\
\text { the } 10 \text { th year }\end{array}$ \\
\hline Input device Reuse & $\begin{array}{l}\text { Increase from } 5 \% \text { up to } 70 \% \\
\text { on the } 10 \text { th year }\end{array}$ & $\begin{array}{l}\text { Increase from } 45 \% \text { up to } 40 \% \\
\text { on the } 10 \text { th year }\end{array}$ & $\begin{array}{l}\text { Increase from } 45 \% \text { up to } 5 \% \\
\text { on the } 10 \text { th year }\end{array}$ \\
\hline $\begin{array}{l}\text { Monitors and CPU with } \\
\text { less than } 3 \text { years }\end{array}$ & $1 \%$ & $1 \%$ & $1 \%$ \\
\hline $\begin{array}{l}\text { Monitors and CPU } \\
\text { between } 4 \text { and } 5 \text { years. }\end{array}$ & $4 \%$ & $4 \%$ & $4 \%$ \\
\hline $\begin{array}{l}\text { Monitors and CPU } \\
\text { between } 6 \text { and } 8 \text { years. }\end{array}$ & $70 \%$ & $70 \%$ & $70 \%$ \\
\hline $\begin{array}{l}\text { Monitors and CPU with } \\
\text { more than } 8 \text { years. }\end{array}$ & $25 \%$ & $25 \%$ & $25 \%$ \\
\hline Remanufacturing Time & 7 days & 7 days & 7 days \\
\hline Energy consumption & $7941 \mathrm{MJ}$ & $7941 \mathrm{MJ}$ & $7941 \mathrm{MJ}$ \\
\hline PCs average price & USD 400 & USD 400 & USD 400 \\
\hline Remanufacturing cost & USD 1 & USD 1 & USD 1 \\
\hline $\begin{array}{l}\text { Value of Carbon Credit } \\
\text { (tons) }\end{array}$ & USD 10 & USD 10 & USD 10 \\
\hline $\begin{array}{l}\text { Energy consumption of } \\
\text { the remanufactured PC }\end{array}$ & $\begin{array}{l}3 \text { years or less - } 31 \% \text { of the } \\
\text { new PC } \\
\text { Between } 4 \text { and } 5 \text { years - } 31 \% \\
\text { of the new PC } \\
\text { Between } 6 \text { and } 8 \text { years - } \\
43.5 \% \text { of the new PC } \\
\text { More than } 8 \text { years - } 116.5 \% \\
\text { of the new PC. }\end{array}$ & $\begin{array}{l}3 \text { years or less - } 31 \% \text { of the } \\
\text { new PC } \\
\text { Between } 4 \text { and } 5 \text { years - } 31 \% \\
\text { of the new PC } \\
\text { Between } 6 \text { and } 8 \text { years - } \\
43.5 \% \text { of the new PC } \\
\text { More than } 8 \text { years - } 116.5 \% \\
\text { of the new PC. }\end{array}$ & $\begin{array}{l}3 \text { years or less - } 31 \% \text { of the } \\
\text { new PC } \\
\text { Between } 4 \text { and } 5 \text { years - } 31 \% \\
\text { of the new PC } \\
\text { Between } 6 \text { and } 8 \text { years - } \\
43.5 \% \text { of the new PC } \\
\text { More than } 8 \text { years - } 116.5 \% \\
\text { of the new PC. }\end{array}$ \\
\hline
\end{tabular}




\subsection{Experiment and results}

Simulations in the Vensim simulator (Ventana Systems, 2016) were performed using computer with Pentium Processor Core i3 and 4 GB of RAM memory. The execution time of simulation was less than one second. The time horizon simulated in the experiment was 10 years. The first analysis refers to the number of computers in use in the country in the next years, because currently, there are approximately 68 million PCs in use and the number of purchased is greater than the number of discarded. The amount of the acquisition in the last three years has suffered a fall (and the sale of tablets rose considerably). In order to evaluate the variable, the number of acquisitions was remained between $7 \%$ and $8 \%$ of total of computers (current rate of acquisition), however, in all three scenarios, with the $5 \%$ rise of quantity of discards by year. The result shows that in the tenth year simulated, the number of personal computers will have a growth of $53 \%$ and the number of discarded computers will increase from 1,7 million a year to 4,2 million. Thus, the result indicates the importance of spreading and implanting IT policies of environmental and financial sustainability for treatment of ICTs to be acquired/discarded. Table 5 shows the variation in the quantity of PCs along the simulated time.

Table 6 shows the total for each group of classification at the end of the simulated time (10 years). In the scenario of reuse of $70 \%$ it could be produced 5,162,148 units, of these, $3,824,130$ would be with discarded units after the use, in the traditional life cycle a period between 6 and 8 years. Even in the scenarios with a smaller reuse index, the numbers are significant, since current numbers (unknown with specific relation to computers reuse) report that Brazil profits little from their solid waste (around 3\%) (Paiva, 2015).

The next analysis performed concerns the financial benefits generated by the sale of remanufactured computers. The possible financial gain was analysed on the simple disposal as waste, on the basis of residual sale prices of post-remanufacturing computers shown in Frota-Neto and Bloemhof (2009). It is evident that in the first two years of simulated time, the gain obtained by the sales is low, but at the end of simulated time, the value of $70 \%$ of reuse scenario is approximately 490 million dollars. In the scenario of reuse of $40 \%$, the gain is 260 million dollars, and in scenario $5 \%$ of reuse the value is 53 million dollars. Figure 7 and Table 7 present the results related to the possible financial benefits of simulated scenarios.

Table 5. Variation in the quantity of PCs (in units)

\begin{tabular}{cccc}
\hline PC & $\mathbf{2 0 1 6}$ & $\mathbf{2 0 2 6}$ & Variation \\
\hline In use & 68 million & 104 million & $53 \%$ \\
Discarded & 1.7 million & 4.2 million & $147 \%$ \\
\hline
\end{tabular}

Table 6. Total computers remanufactured in simulated scenarios (in units)

\begin{tabular}{cccc}
\hline Use of the Devices & Reuse 5\% & Reuse 40\% & Reuse 70\% \\
\hline Less than 3 years & 5,722 & 36,937 & 63,697 \\
Between 4 and 5 years & 18,893 & 126,385 & 218,521 \\
Between 6 and 8 years & 330,659 & $2,211,760$ & $3,824,130$ \\
More than 8 years & 86,676 & 608,512 & $1,055,800$ \\
Total & $\mathbf{4 4 1 , 9 5 0}$ & $\mathbf{2 , 9 8 3 , 5 9 4}$ & $\mathbf{5 , 1 6 2 , 1 4 8}$ \\
\hline
\end{tabular}


At last, the potential for reducing the equipment the stage that consumes more emission of $\mathrm{CO}_{2}$ in the atmosphere from power is its manufacturing $(77 \%$ of total computers remanufacturing was evaluated consumption). The evolution of the annual the. This analysis is based on the premise reduction of the emission of $\mathrm{CO}_{2}$ can be seen that with the extension of the life cycle of a in Figure 8, where it is verified that in all computer, power consumption of a scenarios the reduction has a growth from remanufactured computer is less than of a the 2 nd year. In the scenario reuse of $70 \%$, new one, because in the life cycle of new when the 10th year simulated, emissions

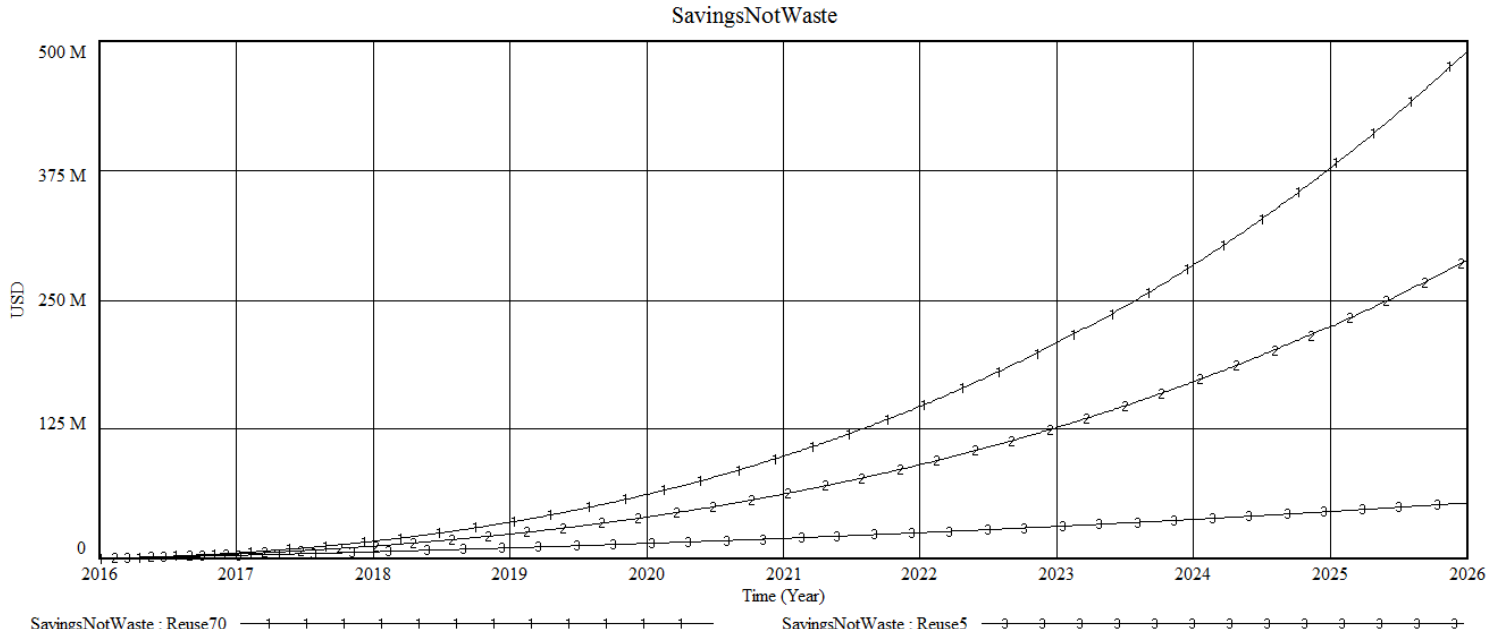

SavingsNotWaste: Reuse $40 \begin{array}{llllllllllllllll}2 & 2 & 2 & 2 & 2 & 2 & 2 & 2 & 2 & 2 & 2 & 2 & 2\end{array}$

Figure 7. Financial benefits obtained by the sale of remanufactured computers

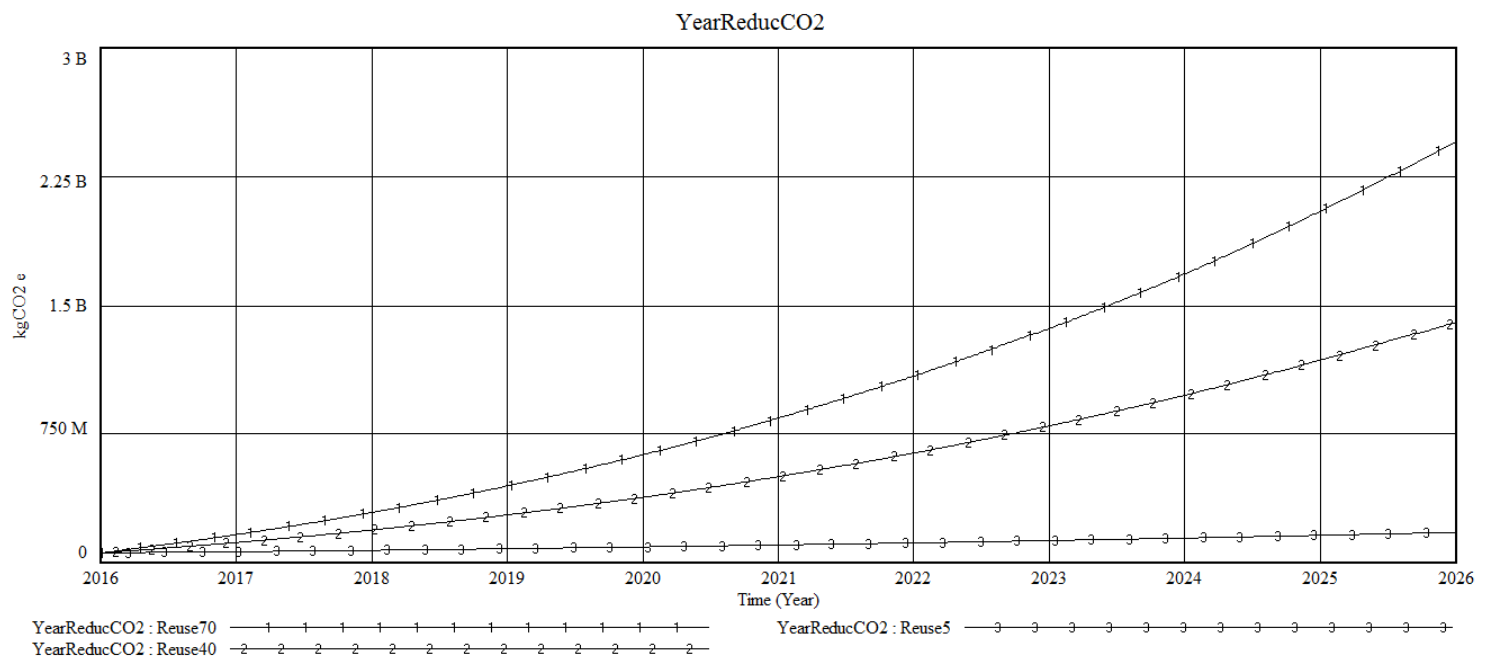

Figure 8. Annual reduction of the $\mathrm{CO}_{2}$ emission with the remanufacturing

Table 7. Total obtained by selling of computers and carbon credits in the 10th year simulated

\begin{tabular}{cccc}
\hline & Reuse 5\% & Reuse 40\% & Reuse 70\% \\
\hline Economy & USD $8,829,610.00$ & USD 70,562,100.00 & USD 123,476,000.00 \\
Carbon Credit & USD $1,668,790.00$ & USD 12,862,100.00 & USD 22,456,500.00 \\
Total & USD 10,498,400.00 & USD 83,424,200.00 & USD 145,932,500.00 \\
\hline
\end{tabular}


were reduced approximately for $2,300,000$ tons of $\mathrm{CO}_{2}$, while in scenario reuse of $40 \%$ the total reduction in emission is, approximately $1,400,000$ tons of $\mathrm{CO}_{2}$. In the scenario of reuse of $5 \%$ reduction of the emission of $\mathrm{CO}_{2}$ in the last year of the simulation is 175,000 tons of $\mathrm{CO}_{2}$. A comparative analysis with the current situation of emission of $\mathrm{CO}_{2}$ is difficult to implement because there are no data on the destination of each equipment after its disposal as electronic waste. The annual data on the reduction of $\mathrm{CO}_{2}$ emission can be seen in Figure 8, while in Table 7 the total of financial value is shown, i.e. the total values obtained by the possible sale of remanufactured computers plus the total carbon credits from the remanufacturing.

\section{CONCLUDING REMARKS}

The main objective of this research was the development, experimental verification and validation of remanufacturing strategy through computational simulation models and different scenarios to prove that environmental and financial impacts caused by the extension of the life cycle of personal computers are possible through their remanufacturing. From the results obtained through simulations, public managers get possibilities to define new policies involving the discard of computers, taking into account the financial and environmental sustainability in the decision-making process with respect to the cost of waste management. The proposed and proved model is a reconfigurable and open model. With regard to results obtained, for the scenarios evaluated, the scenario reuse of $70 \%$ gives better results than the other two, both in environmental and financial benefits sense. It is also noticeable that all scenarios with remanufacturing are better than the current situation, regarding the reutilization of the electronic waste and It is evident that even an index of 5\% of remanufacturing produces good results. As future studies, it is aimed to expand the model to other equipment not considered in the study, such as printers, notebooks and smartphones, and also to consider the social benefits that can be generated, such as to donate part of computers produced to the institutions which do not have the purchase conditions. The main limitation of this research consists of the absence of market analysis for the remanufactured computers. However, this limitation can cause a new research to be developed.

\section{Acknowledgements}

The authors wish to acknowledge the support of the Coordenação de Aperfeiçoamento de Pessoal de Nível Superior (CAPES) - Grant reference BEX 0004-15-4, the support of the Fundação para a Ciência e Tecnologia (FCT), Portugal, within the Project Reference PestUID/CEC/00319/2013 and the "Ph.D. Scholarship Grant" reference SFRH/BD/85672/2012 and the support of MESTD within the project SPRINCE, no. 22, ERA-NET SAF€RA programm.

\section{References}

Abeliotis, K., Karaiskou, K., Togia, A., \& Lasaridi, K. (2009). Decision support systems in solid waste management: a case study at the national and local level in Greece. Global NEST Journal, 11 (2), 117 126. 


\title{
МОДЕЛ ДИНАМИКЕ СИСТЕМА ЗА ЕВАЛУАЦИЈУ ПОНОВНЕ УПОТРЕБЕ ЕЛЕКТРОНСКОГ ОТПАДА КОЈИ ПОТИЧЕ ОД ПЕРСОНАЛНИХ КОМПЈУТЕРА
}

\author{
Eugênio Simonetto, Osvaldo Quelha, Весна Спасојевић Бркић, Горан Путник, \\ Cátia Alves, Hélio Castro
}

\section{Извод}

Информационе и комуникационе технологије (ИЦТ) су део свакодневних активности великог дела светске популације, ипак, њихова употреба доводи до пораста количине електронског отпада (е-отпад). Као последица растућег броја технолошких иновација, делује да за кратко време, производи постају застарели те да им се смањује животни циклус. Овај рад има за циљ да представи развој, верификацију и валидацију модела компјутерске симулације за процену еколошких и финансијских утицаја које може изазвати продужење животног циклуса персоналних рачунара (ПЦ) кроз њихову репроизводњу. За моделовање система, употребљена је теорија динамике система. Резултати добијени на основу симулационог модела, показују да је репроизводња могућа алтернатива за поновну употребу одбачених рачунара, као и да је могуће унапред анализирати, проценити и одабрати неопходне мере за боље финансијке и еколошке перформансе код набавке и употребе ИЦТ.

Кључне речи: Динамика система, надоградња рачунара, поновна употреба, електронски отпад

Bhat, V. N. (1996). A model for the optimal allocation of trucks for solid waste management. Waste Management \& Research, 14(1), 87-96.

Daellenbach, H., McNickle, D., \& Dye, S. (2012). Management science: decisionmaking through systems thinking. Palgrave Macmillan.

de Oliveira Simonetto, E., \& Borenstein, D. (2007). A decision support system for the operational planning of solid waste collection. Waste Management,27(10), 12861297.

Dias, G.F., Ramos, A.M., Oliveira, B.K., Damasceno, L.S., \& Andrade, A.V. (2013). Organizational practices environmentally sound related to Information Technology: a qualitative study in the best Brazilian universities. Proc. XXXVII En Anpad. (In Portuguese)
Djordjevic, P., Mihajlovic, I., Zivkovic, Z. (2010). Comparison of linear and nonlinear statistics methods applied in industrial process modeling procedure, Serbian Journal of Management, 5 (2), 189-198.

Dragićević, S., \& Bojić, M. (2009). Application of linear programming in energy management. Serbian Journal of Management, 4 (2), 227-238.

Dyson, B., \& Chang, N.B. (2005). Forecasting municipal solid waste generation in a fast-growing urban region with system dynamics modeling. Waste Management, 25 (7), 669- 679.

EPA. United States Environmental Protection Agency. (2016). Carbon footprint calculator. Available at: http://www3.epa.gov/carbon-footprintcalculator/.Accessed: February 2016.

Everett, J. W., \& Shahi, S. (1997). Vehicle 
and labor requirements for yard waste collection. Waste management \& research, 15(6), 627-640.

Faria, A.C., Martins, M.S., \& Siqueira, L.D. (2013). Green IT: Myth or Reality Digital Brazilian Industry. Proc. XXXVII EnAnpad. (In Portuguese)

Ferrer, G. (1997). The economics of personal computer remanufacturing. Resources, Conservation and Recycling, 21 (1), 79-108.

Ford, A. (2009). Modeling the Environment. Island Press.

Frota-Neto, J.Q., \& Bloemhof, J.M. (2009). Is Remanufacturing Effective and Eco-Efficient? An Analysis of the EcoEfficiency of Personal Computers and Mobile Phones, Social Science Research Network, Available at SSRN: http://ssrn.com/abstract $=1367023$

Frota-Neto, J.Q., \& Bloemhof, J.M. (2012). An Analysis of the Eco-Efficiency of Remanufactured Personal Computers and Mobile Phones. Production and Operations Management, 21 (1), 101-114.

Giutini, R., \& Gaudette, K. (2003). Remanufacturing: the next great opportunity for boosting US productivity. Business Horizon, 46 (6), 41-48.

Golroudbary, S.R., \& Zahraee, S.M. (2015). System dynamics model for optimizing the recycling and collection of waste material in a closed-loop supply chain. Simulation Modelling Practice and Theory, 53 (1), 88-102.

Hatcher, G.H., Ijomah, W.L., \& Windmill, J.F.C. (2013). Design for remanufacturing in China: a case study of electrical and electronic equipment. Journal of Remanufacturing, 3 (3), 1-11.

Huang, G. H., Baetz, B. W., \& Patry, G. G. (1998). Trash-flow allocation: planning under uncertainty. Interfaces, 28(6), 36-55.
Kroth, G.L., Simonetto, E.O., Löbler, M.L., Gubiani, J.S., \& Schiefelbein, U. (2015). Computer simulation to evaluate the environmental impact generated by the information technology sector. Proc. XXXV ENEGEP - National Meeting of Production Engineering. ABEPRO. (In Portuguese)

Kum, V., Sharp, A., \& Harnpornchai, N. (2005). A System Dynamics Study of Solid Waste Recovery Policies in Phnom Penh City. 23rd International Conference of the System Dynamics Society, Boston, Systems Dynamics Society.

Law, A.M. (2015). Simulation Modeling and Analysis. 5th Ed., McGraw-Hill.

Lunardi, G.L., Frio, R.S., \& Brum, M.M. (2011). Information Technology and Sustainability: A study of dissemination of Green IT practices in organizations. XXXV En Anpad. (In Portuguese)

Lunardi, G.L., Alves, A.P.F., \&Salles, A.C. (2014). Development of a scale to assess the degree of use of green information technology by organizations. R. Adm., 49 (3), 591-605. (In Portuguese)

Meirelles, F. (2015). 26th. Annual Survey of Information Technology. Getulio Vargas Foundation (FGV). (In Portuguese)

Murugesan, S. (2008). Harnessing green IT: Principles and practices. IT professional, 10(1), 24-33.

Paiva, R. (2015). Only 3\% of all waste produced in Brazil is recycled. Jornal Hoje. Globo. Acessed in: 25 mar 2016. Available at: http://g1.globo.com/jornal-hoje/noticia/ 2015/04/apenas-3-de-todo-o-lixo-produzidono-brasil-e-reciclado.html . (In Portuguese)

Parkes, O., Lettieri, P., \& Bogle, D.L. (2015). Life cycle assessment of integrated waste management systems for alternative legacy scenarios of the London Olympic Park. Waste Management, 40 (1), 157-166.

Perrodin, Y., Gobbey, A., Grelier-Volatier, 
L., Canivet, V., Fruget, J. F., Gibert, J., ... \& Jocteur-Monrozier, L. (2002). Waste ecocompatibility in storage and reuse scenarios: global methodology and detailed presentation of the impact study on the recipient environments. Waste Management, 22(2), 215-228.

Poles, R., \& Cheong, F. (2009). A System Dynamics Model for Reducing Uncertainty in Remanufacturing Systems. Pacific Asia Conference on Information Systems. PACIS 2009. AIS.

Sahni,S., Boustani, A., Gutowski, T., \& Graves, S. (2010). Personal Computer Remanufacturing and Energy Savings. Technical Report, MIT Energy Initiative Report Series.

Savic, M.V., Djordjevic, P.B., Mihajlovic, I.N., Zivkovic, Z.D. (2015). Statistical modeling of copper losses in the silicate slag of the sulfide concentrate smelting process. Polish Journal of Chemical Technology, 17 (3), 62-69.

Schneider, J.R., Zwicker, A.M., Beltrame, G., \& Simonetto, E.O. (2015). Simulation for evaluating scenarios of generation and disposal of electronic waste in a higher education institution. XVIII SemeAd. University of São Paulo. (In Portuguese)

Simonetto, E.O. (2014). Simulation computer to evaluate scenarios of solid waste - an approach using systems dynamics. International Journal of Environment and Sustainable Development, 13 (4), 339-353.

Sufian, M.A., \& Bala B.K. (2007). Modeling of urban solid waste management system: The case of Dhaka city. Waste Management, 27 (7), 858-868.

Sundin, E., \& Dunbäck, O. (2013). Reverse logistics challenges in remanufacturing of automotive mechatronic devices. Journal of Remanufacturing, 3 (2), 1-8.
Ventana Systems. (2016). Vensim Simulation Software. Available at: http://www.vensim.com .Accessed in: feb. 2016.

Vlachos, D., Georgiadis, P., \& Iakovou, E. (2007). A system dynamics model for dynamic capacity planning of remanufacturing in closed-loop supply chains. Computers \& Operations Research. 34 (2), 364-397.

Zutshi, A., \& Sohal, A. S. (2002). Environmental management systems auditing: auditors experiences in Australia. International journal of environment and sustainable development, 1(1), 73-87. 